\title{
Selecting native entomopathogenic fungi against Cosmopolites sordidus (Germar) in the laboratory
}

\author{
Seleção de fungos entomopatogênicos nativos contra Cosmopolites sordidus (Germar) em \\ laboratório
}

\author{
Junior Steve Garrido Pérez ${ }^{1,2}$, Richard Paredes-Espinosa ${ }^{3}$, Giannfranco Egoávil Jump ${ }^{1}$, Oniel \\ Jeremias Aguirre $\mathrm{Gil}^{3,4 *}$
}

\author{
${ }^{1}$ Universidad Nacional Agraria de la Selva, Tingo María, Peru. \\ ${ }^{2}$ Palmas del Espino S.A., Uchiza, Perú. \\ ${ }^{3}$ Instituto Nacional de Innovación Agraria, Tarapoto, Peru. \\ ${ }^{4}$ Universidade Estadual Paulista "Júlio de Mesquita Filho", Jaboticabal, SP, Brasil. * Author for correspondence: oniel.aguirre@unesp.br
}

Submission: 27/07/2020 / Acceptance: 14/12/2020

\begin{abstract}
The objective of this study was to select native isolates of entomopathogenic fungi against adult Cosmopolites sordidus in laboratory conditions. Four isolates of Beauveria bassiana, two isolates of Metarhizium anisopliae, and two isolates of Paecilomyces lilacinus were tested against $C$. sordidus. The entomopathogenic fungi that resulted in mortality rates over $50 \%$ were $M$. anisopliae (MA-CsCha and MACarabid) and B. bassiana (BB-CsCha and BB-CsLp). The most virulent isolates were MA-CsCha, BBCsCha, and MA-Carabid with median lethal times (LT50) of 4.82, 5.4, and 5.79 days, respectively. In conclusion, the MA-CsCha, BB-CsCha, MA-Carabid, and BB-CsLp isolates are viable candidates to be tested in banana fields.
\end{abstract}

KEYWORDS: banana root borer, Beauveria bassiana, Metarhizium anisopliae, biocontrol.

\section{RESUMO}

Este estudo teve como objetivo selecionar isolados de fungos entomopatogênicos contra adultos de Cosmopolites sordidus em condições de laboratório. Quatro isolados de Beauveria bassiana, dois isolados de Metarhizium anisopliae e dois isolados de Paecilomyces lilacinus foram testados contra $C$. sordidus. Os fungos entomopatogênicos que resultaram em mais de $50 \%$ da mortalidade de adultos de $C$. sordidus foram M. anisopliae (MA-CsCha e MA-Carabid) e B. bassiana (BB-CsCha e BB-CsLp). Os isolados mais virulentos foram MA-CsCha, BB-CsCha e MA-Carabid com um tempo letal médio (TL50) de 4,82, 5,4 e 5,79 dias, respectivamente. Em conclusão, os isolados MA-CsCha, BB-CsCha, MA-Carabid e BB-CsLp são candidatos para serem testados em plantações de banana.

PALAVRAS-CHAVE: Moleque-da-bananeira, Beauveria bassiana, Metarhizium anisopliae, biocontrole.

The banana crop is important because it contributes to food security with an annual production of about 127 million tons worldwide (NYINE \& PILLAY 2007, FAOSTAT 2020). However, the commercial crop faces problems caused by pests, and the Banana Root Borer (BRB), Cosmopolites sordidus (Germar), which infests the cortical tissues, can generate losses of up to $100 \%$ of the harvest (AKELLO et al. 2008, OLIVEIRA et al. 2017).

In this context, entomopathogenic fungi are an integrated pest management tool and an important alternative to insecticides against the BRB (OLSON 2015). There is a wide distribution of entomopathogenic fungi, which means they have a high genetic variability and distinct levels of virulence and local adaptability (NIASSY et al. 2013). Therefore, suitable isolates should be selected to control BRB populations according to the abovementioned aspects, since these studies are scarce under Peruvian conditions.

The entomopathogens Beauveria bassiana (Bals.) Vuill. (now Cordyceps bassiana) and Metarhizium anisopliae (Metsch.) Sorokin have been shown to be the most promising biocontrol agents against BRB due to their cosmopolitan distribution and high lethality caused by their production of mycotoxins and growth which blocks the insect's digestive tract (TINZAARA et al. 2015, SALUSTINO et al. 2019). These species are 
reported to cause infections for more than 300 species of pest insects (MOREIRA et al. 2017), which implies that this high genetic variability should be studied in order to select efficient entomopathogenic fungi adapted to the conditions where it is necessary to control BRB. Furthermore, the discovery of new native isolates with high virulence and infectivity can add value to biological control methods by reducing production costs and the use of conventional insecticides in banana fields (MEMBANG et al. 2020).

The objective of this study was to select native entomopathogenic fungi as potential biocontrol agents of $C$. sordidus populations in a humid tropic climate. The hypothesis was that at least one entomopathogenic fungus in the study would reach a $50 \%$ mortality rate within seven days after inoculation. Therefore, the results of this study offer new opportunities to discover potential entomopathogenic fungi that can be used in field using local and exotic isolates.

The study was conducted in the Laboratory of Entomopathogens at the Universidad Nacional Agraria de la Selva (UNAS), Tingo María, Peru (9¹8'48" S, 7559'45" W, $668.6 \mathrm{~m}$ above sea level), which has a humid tropical climate (Af) based on the Köppen-Geiger classification (PEEL et al. 2007). The eight entomopathogenic fungi tested in this study were obtained from the Servicio Nacional de Sanidad Agraria (SENASA) and UNAS collections. In the laboratory, four isolates of Beauveria bassiana, two isolates of Metarhizium anisopliae, and two isolates of Paecilomyces lilacinus (Tom) Samson were tested against $C$. sordidus. Information about the collections is presented in Table 1.

The entomopathogenic fungi were cultured in Petri dishes $(8.5 \mathrm{~cm}$ diameter) containing Potato Dextrose Agar (PDA) at $24 \pm 5{ }^{\circ} \mathrm{C}$ for ten days. The Petri dishes and PDA were previously autoclaved at $121^{\circ} \mathrm{C}, 15 \mathrm{lbs}$ for 15 minutes.

After ten days, entomopathogenic fungi were sown in an artificial substrate. The artificial substrate had been prepared as follows: $200 \mathrm{~g}$ rice and $40 \mathrm{~mL}$ water placed in a polypropylene bag $(8 \times 12 \mathrm{~cm})$; the bags were then folded, stapled closed, and autoclaved at $121^{\circ} \mathrm{C}, 15 \mathrm{lbs}$ for 15 minutes. Entomopathogenic fungi were sown in an artificial substrate in a laminar flow cabinet.

The bags with entomopathogenic fungi were stored on metal shelves in a room at $24 \pm 5{ }^{\circ} \mathrm{C}$ and incubated for ten days. The bags were shaken daily to homogenize the internal content.

Table 1. Description of the isolates.

\begin{tabular}{|c|c|c|}
\hline Isolate codes & Scientific name & Origin \\
\hline $\mathrm{BB}-\mathrm{Hh}$ & Beauveria bassiana & $\begin{array}{l}\text { Hypothenemus hampei collected in Sania Province, Peru } \\
\text { (SENASA, commercial code: CCB-LE265) }\end{array}$ \\
\hline BB-CsCha & Beauveria bassiana & $\begin{array}{l}\text { Cosmopolites sordidus collected in Chanchamayo Province, } \\
\text { Peru (SENASA, commercial code: CCB-LE2118) }\end{array}$ \\
\hline BB-CsLp & Beauveri & $\begin{array}{l}\text { Cosmopolites sordidus collected in Leoncio Prado Province, } \\
\text { Peru (UNAS) }\end{array}$ \\
\hline $\mathrm{BB}-\mathrm{CsVr}$ & Beauve & $\begin{array}{l}\text { Cosmopolites sordidus collected in Villa Rica District, Peru } \\
\text { (UNAS) }\end{array}$ \\
\hline PL-Milt & aecilom & $\begin{array}{l}\text { gyne incognita collected in Italy (SENASA, commercial } \\
\text { CB-LE 701) }\end{array}$ \\
\hline PL-CsChi & Paecilomyces lilacinus & olites sordidus collected in Chiclayo Province (UNAS) \\
\hline MA-C & Metarhizic & $\begin{array}{l}\text { Unidentified Carabid specimen in Peru (SENASA, commercial } \\
\text { code: CCB-LE302) }\end{array}$ \\
\hline MA-CsCha & Metarhizium anisopliae & $\begin{array}{l}\text { Cosmopolites sordidus collected in Chanchamayo Province, } \\
\text { Peru (SENASA, commercial code: CCB-LE319) }\end{array}$ \\
\hline Control & - & Sterile water \\
\hline
\end{tabular}

For the conidial suspension, a ten-day-old fungal colony was diluted in sterile distilled water and mixed with Tween $80^{\circledR}(0.05 \%)$. Then, the mixture was filtered through sterilized gauze to separate the conidia from the mycelium and other impurities. The quantity of conidia contained in the mixture were registered using a Neubauer chamber and then adjusted to a concentration of $10^{8}$ conidia $\mathrm{mL}^{-1}$. This concentration was used for the findings obtained by MEMBANG et al. (2020).

Adult Cosmopolites sordidus were collected in a banana field at Los Milagros Village, Tingo María, Peru. Traps formed by $10 \mathrm{~cm}$ banana stalks were used to attract $C$. sordidus in the field. One week later, adult $C$. sordidus were collected from the traps and placed in plastic boxes to be transported. In the laboratory, the adult $C$. sordidus were sprayed with and immersed in sodium hypochlorite $(0.5 \%)$ for disinfection and then rinsed with sterile water three times. Only the more active ones of these insects were 
used in the experiment.

A completely randomized design with nine treatments was adopted to determine the mortality rates and lethal times of entomopathogenic fungi isolates (Table 1) against $C$. sordidus in the laboratory.

For each isolate, an experiment was conducted with three replicates. One replicate consisted of a group of 15 healthy adult $C$. sordidus that were individually sprayed with the solution containing the entomopathogens until they were dripping. A total of 45 adult $C$. sordidus were used per isolate. The sprayed insects were then conditioned in Petri dishes $(10 \mathrm{~cm}$ diameter) containing banana stalks, which had been disinfected with $0.5 \%$ sodium hypochlorite solution for five min, in order to feed.

The number of active $C$. sordidus were evaluated for 21 days after infection. The mortality rate was calculated by the percentage of dead insects from total insects. Dead insects were individually maintained in Petri dishes lined with moistened filter paper to allow fungal sporulation.

The mortality rate percentage $(x)$ under laboratory conditions was transformed by arcsine $(x / 100)^{1 / 2}$. To obtain the median lethal times (LT50) of the isolates against $C$. sordidus, a Probit analysis was conducted. Data were analyzed using the $R$ software for Windows (R CORE TEAM 2016). Cumulative mortality rates were corrected using Abbott's formula. Normality and equality of variance were tested by the Kolmogorov-Smirnov and the Levene's tests, respectively $(p \leq 0.05)$. The mortality rate percentage was analyzed as a response variable in one-way (isolate) ANOVA. Whenever a significant F-test $(p \leq 0.05)$ was detected, the mean values for mortality were compared with Tukey's test (HSD) at $(p \leq 0.05)$. The values of LT50 and LT90 of the isolates were estimated at 95\% confidence levels (CL) using the Probit analysis with the "ecotoxicology" Package (GAMA 2015).

In total, 878 adult $C$. sordidus were collected for the study. The experiment revealed the ability of entomopathogenic fungi isolates to control $C$. sordidus adults under laboratory conditions. The MA-CsCha isolate resulted in a $57.78 \%$ mortality rate for adult $C$. sordidus five days after inoculation in the laboratory (Table 2). However, the MA-CsCha, BB-CsCha, MA-Carabid, and BB-CsLp isolates resulted in mortality rates of over $50 \%$ for adult $C$. sordidus seven days after inoculation.

According to the Probit regression, the MA-CsCha isolate resulted in a $50 \%$ mortality rate for $C$. sordidus 4.82 days after inoculation (Figure $1 \mathrm{~A}$ ). However, the BB-CsCha isolate resulted in a $90 \%$ mortality rate for $C$. sordidus in 8.04 days (Figure $1 C$ ). The differences between isolates are explained by the slope indicating that the rate of mortality increases 7.44 times per day for adult $C$. sordidus inoculated with BBCsCha.

Table 2. Mortality rates (\%) for adult Cosmopolites sordidus infected with entomopathogenic fungi in the laboratory.

\begin{tabular}{lrcc}
\hline \multirow{2}{*}{ Treatments } & \multicolumn{3}{c}{ Days after infection } \\
\cline { 2 - 4 } & 5 & 6 & 7 \\
\hline MA-CsCha & $57.78 \mathrm{a}$ & $71.11 \mathrm{a}$ & $82.22 \mathrm{a}$ \\
BB-CsCha & $24.44 \mathrm{~b}$ & $77.78 \mathrm{a}$ & $82.22 \mathrm{ab}$ \\
MA-Carabid & $8.89 \mathrm{~b}$ & $73.33 \mathrm{a}$ & $84.44 \mathrm{a}$ \\
BB-Hh & $13.33 \mathrm{~b}$ & $28.89 \mathrm{~b}$ & $33.33 \mathrm{~cd}$ \\
BB-CsLp & $13.33 \mathrm{~b}$ & $24.44 \mathrm{bc}$ & $53.33 \mathrm{bc}$ \\
PL-Milt & $4.44 \mathrm{~b}$ & $4.44 \mathrm{c}$ & $4.44 \mathrm{e}$ \\
PL-CsChi & $4.44 \mathrm{~b}$ & $6.67 \mathrm{bc}$ & $11.11 \mathrm{de}$ \\
BB-CsVr & $2.22 \mathrm{~b}$ & $6.67 \mathrm{bc}$ & $11.11 \mathrm{de}$ \\
\hline
\end{tabular}

Mean values followed by different letters in the same column are significantly different based on Tukey's test $(p \leq 0.05)$

Metarhizium anisopliae and $B$. bassiana infect a wide range of hosts in numerous insect orders, including Orthoptera, Lepidoptera, Dermaptera, Diptera, and Coleoptera (MAINA et al. 2018). However, in order to select isolates and use them for biological control, it is fundamental to understand the mortality rate and lethal time (kill at least $50 \%$ individuals) of an entomopathogenic fungus on a specific target pest (BAYISSA et al. 2017, MWEKE et al. 2018, MAHOT et al. 2019). This study reports on two isolates of $M$. anisopliae (MA-CsCha, MA-Carabid) and two isolates of B. bassiana (BB-CsCha, BB-CsLp), which can cause mortality rates of over $50 \%$ for adult $C$. sordidus under laboratory conditions. In Brazil, FANCELLI et al. (2013) reported similar results, wherein native isolates of $B$. bassiana promoted mortality rates (14 - 96\%) for adult $C$. sordidus in laboratory experiments. The most virulent isolates achieved a LT50 of 4.82, 5.40, and 5.79 days (Figure 1), which were faster than the most virulent isolates reported by FANCELLI et al. (2013), 
GONZÁLEZ et al. (2018), and LOPES et al. (2011).

On the other hand, some studies have reported that exotic isolates can possibly be more effective than native isolates (LOPES et al. 2013). Although it is not a rule, this study used exotic isolates from Sania (BB-Hb), Villa Rica (BB-CsVr), Chiclayo Province (PL-CsChi), and Italy (PL-Milt), which did not present relevant results.
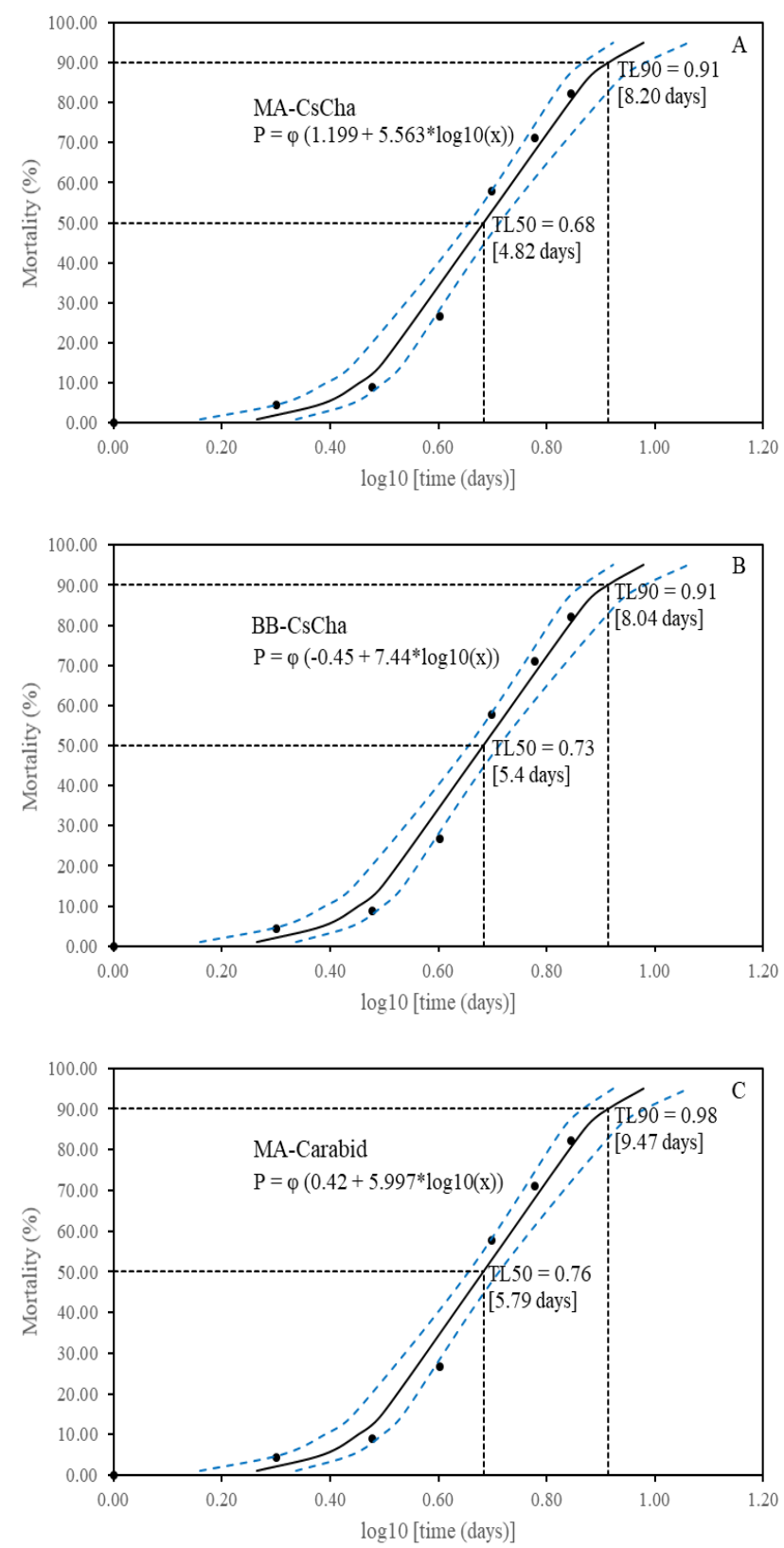

Figure 1. Mortality rates for adult Cosmopolites sordidus caused by infection from isolates MA-CsCh (A), BB$\mathrm{CsCh}(\mathrm{B})$, and MA-Carabid (C) over time, according to the Probit regression.

The findings also indicate variations between and within entomopathogenic fungi isolates, as reported by CHENG et al. (2016). Therefore, an individual belonging to the same fungal species is not a guarantee for similar virulence, because isolates can use different types and quantities of enzymes and metabolites to infect the insect host (ABDELAZIZ et al. 2018).

Future studies should use combinations of different species of biological control agents so as to increase the effects against pests, reduce insecticide use, and minimize environmental pollution risks and pest resistance (REDDY et al. 2014, CARVALHO 2017).

The results of this study indicate suitable entomopathogenic candidates to be tested in banana crops against $C$. sordidus. In conclusion, the native isolates of Metarhizium anisopliae (MA-CsCha and MACarabid) and Beauveria bassiana (BB-CsCha and BB-CsLp) were selected as potential biocontrol agents against $C$. sordidus. 


\section{ACKNOWLEDGEMENTS}

The authors thank the Facultad de Agronomía - Universidad Nacional Agraria de la Selva and the Estación Experimental Agraria El Porvenir - Instituto Nacional de Innovación Agraria for their support in this project.

\section{REFERENCES}

ABDELAZIZ O et al. 2018. Pathogenicity of three entomopathogenic fungi, to the aphid species, Metopolophium dirhodum (Walker) (Hemiptera: Aphididae), and their Alkaline protease activities. Egyptian Journal of Biological Pest Control 28: 24.

AKELLO J et al. 2008. Effect of endophytic Beauveria bassiana on populations of the banana weevil, Cosmopolites sordidus, and their damage in tissue-cultured banana plants. Entomologia Experimentalis et Applicata 129: 157-165.

BAYISSA W et al. 2017. Selection of fungal isolates for virulence against three aphid pest species of crucifers and okra. Journal of Pest Science 90: 355-368.

CARVALHO FP. 2017. Pesticides, environment, and food safety. Food and Energy Security 6: 48-60.

CHENG Y et al. 2016. Evaluation of Pathogenicity of the fungi Metarhizium anisopliae and Beauveria bassiana in hazelnut weevil (Curculio nucum L., Coleoptera, Curculionidae) Larvae. Indian Journal of Microbiology 56: 405-410.

FANCELLI M et al. 2013. Beauveria bassiana strains for biological control of Cosmopolites sordidus (Germ.) (Coleoptera: Curculionidae) in plantain. BioMed Research International 2013: 1-7.

FAOSTAT. 2020. Crop statistics. Database. Available in: http://www.fao.org/faostat/en/\#data/QC. Accessed in: 27 jul. 2020.

GAMA J. 2015. Ecotoxicology: Methods for Ecotoxicology (R package version 1.0.1) [Computer software]. Available in: https://CRAN.R-project.org/package=ecotoxicology. Accessed in: 27 feb. 2020.

GONZÁLEZ DN et al. 2018. Suitability of Cordyceps bassiana and Metarhizium anisopliae for biological control of Cosmopolites sordidus (Germar) (Coleoptera: Curculionidae) in an organic Mexican banana plantation: laboratory and field trials. Journal of Plant Diseases and Protection 125: 73-81.

LOPES RB et al. 2013. Diversity of indigenous Beauveria and Metarhizium spp. in a commercial banana field and their virulence toward Cosmopolites sordidus (Coleoptera: Curculionidae). Fungal Ecology 6: 356-364.

LOPES RB et al. 2011. Virulence and horizontal transmission of selected Brazilian strains of Beauveria bassiana against Cosmopolites sordidus under laboratory conditions. Bulletin of Insectology 64: 201-208.

MAHOT HC et al. 2019. Laboratory assessment of virulence of Cameroonian isolates of Beauveria bassiana and Metarhizium anisopliae against mirid bugs Sahlbergella singularis Haglund (Hemiptera: Miridae). African Entomology 27: 86-96.

MAINA UM et al. 2018. A review on the use of entomopathogenic fungi in the management of insect pests of field crops. Journal of Entomology and Zoology Studies 6: 27-32.

MEMBANG G et al. 2020. Cosmopolites sordidus (Germar) susceptibility to indigenous Cameroonian Beauveria bassiana (Bals.) Vuill. and Metarhizium anisopliae (Metsch.) isolates. Journal of Applied Entomology 144: 468-480.

MOREIRA FJC et al. 2017. Controle de Cosmopolites sordidus (Coleoptera: Curculionidae) com os fungos entomopatogênicos Beauveria bassiana e Metarhizium anisopliae em banana. Revista Verde de Agroecologia e Desenvolvimento Sustentável 12: 366-373.

MWEKE A et al. 2018. Evaluation of the entomopathogenic fungi Metarhizium anisopliae, Beauveria bassiana and Isaria sp. for the management of Aphis craccivora (Hemiptera: Aphididdae). Journal of Economic Entomology 111: 15871594.

NIASSY S et al. 2013. Use of Metarhizium anisopliae Chitinase genes for genotyping and virulence characterization. BioMed Research International 2013: 1-9.

NYINE M \& PILLAY M. 2007. Banana nectar as a medium for testing pollen viability and germination in Musa. African Journal of Biotechnology 6: 1175-1180.

OLIVEIRA F et al. 2017. Infestation of the banana root borer among different banana plant genotypes. Ciência Rural 47: e20151114.

OLSON S. 2015. An analysis of the biopesticide market now and where it is going. Outlooks on Pest Management 26: 203-206.

PEEL MC et al. 2007. Updated world map of the Köppen-Geiger climate classification. Hydrology Earth System Scientia 11: 1633-1644.

R CORE TEAM. 2016. R: A Language and Environment for Statistical Computing (3.3.1) [En]. R Foundation for Statistical Computing. Available in: https://www.R-project.org/. Accessed in: 27 jul. 2020.

REDDY GVP et al. 2014. Laboratory and field efficacy of entomopathogenic fungi for the management of the sweetpotato weevil, Cylas formicarius (Coleoptera: Brentidae). Journal of Invertebrate Pathology 122: 10-15.

SALUSTINO ADS et al. 2019. Olfactory attraction of rhizome borer (Coleoptera: Curculionidae) to banana genotypes inoculated with entomopathogenic fungus. Journal of Experimental Agriculture International 40: 1-6.

TINZAARA W et al. 2015. Enhancing dissemination of Beauveria bassiana with host plant base incision trap for the management of the banana weevil Cosmopolites sordidus. African Journal of Agricultural Research 10: 3878-3884. 